\title{
Kepuasan Kerja dan Integritas sebagai Pemoderasi Pengaruh Penerapan Sistem Informasi Akuntansi pada Kinerja Karyawan
}

\author{
A.A Bagus Surya Nayaka ${ }^{1}$ \\ I Made Sadha Suardikha ${ }^{2}$ \\ ${ }^{1,2}$ Fakultas Ekonomi dan Bisnis Universitas Udayana (Unud), Bali, Indonesia \\ e-mail: suryanayaka12@gmail.com
}

\begin{abstract}
ABSTRAK
Setiap perusahaan wajib memberikan suatu informasi dari hasil proses akuntansi setiap periodenya untuk memenuhi kebutuhan informasi keuangan bagi pihak-pihak yang memiliki kepentingan. Tujuan penelitian ini adalah untuk mengetahui pengaruh penerapan SIA terhadap kinerja karyawan dengan kepuasan kerja dan integritas sebagai pemoderasi. Penelitian ini dilaksanakan pada BPD Bali di Kota Denpasar. Sampel dalam penelitian ini berjumlah 80 orang yang diperoleh dengan teknik non-probability sampling dengan metode sampling jenuh. Pengumpulan data dilakukan dengan metode survei menggunakan kuesioner. Teknik analisis data dilakukan dengan analisis regresi linier sederhana dan Moderated Regression Analysis. Hasil penelitian menunjukkan SIA yang telah diterapkan pada BPD Bali di Kota Denpasar mampu meningkatkan kinerja karyawan. Penelitian ini juga menemukan bahwa kepuasan kerja memperkuat pengaruh penerapan SIA pada kinerja karyawan BPD Bali di Kota Denpasar. Selain itu, penelitian ini juga menunjukkan bahwa integritas yang dimiliki karyawan tidak memperkuat atau memperlemah pengaruh penerapan SIA pada kinerja karyawan BPD Bali di Kota Denpasar.

Kata kunci: sistem informasi akuntansi, kinerja karyawan, kepuasan kerja, integritas.
\end{abstract}

\begin{abstract}
Each company is required to provide information from the accounting process results of each period to meet the needs of financial information for parties who have an interest. The purpose of this study is to determine the effect of SIA implementation on employee performance with job satisfaction and integrity as a moderator. This research was conducted at BPD Bali in Denpasar City. Sample in this study amounted to 80 people. Data analysis technique is done by simple linear regression analysis and Moderated Regression Analysis. The results showed that SIA that has been applied to BPD Bali in Denpasar City able to improve employee performance. This study also found that job satisfaction strengthens the influence of SIA implementation on the performance of employees and the integrity of the employees does not strengthen or weaken the influence of SIA implementation on the performance of BPD Bali employees in Denpasar City.

Keywords: accounting information system, employee performance, job satisfaction, integrity.
\end{abstract}

\section{PENDAHULUAN}

Dewasa ini perkembangan teknologi di dunia semakin maju yang dibuktikan dengan munculnya banyak perangkat teknologi sebagai sarana penunjang hidup masyarakat. Perkembangan tersebut juga merambah pada ranah bidang informasi 
A.A Bagus Surya Nayaka dan I Made Sadha Suardikha. Kepuasan...

khususnya bidang informasi akuntansi pada dunia perusahaan. Perkembangan yang terjadi pada bidang informasi akuntansi menyebabkan berkembangnya kebutuhan informasi bagi pihak-pihak yang berkepentingan dan dibutuhkannya proses serta kinerja yang berkualitas dalam menghasilkan informasi. Persaingan antar perusahaan juga menjadi salah satu hal yang perlu diperhatikan untuk tetap dapat kompetitif dan menjawab setiap tantangan perusahaan dari masyarakat. Pada proses menghasilkan informasi akuntansi sehari-hari dilaksanakan menurut sistem yang diterapkan pada setiap perusahaan masing-masing dan pelaksanaannya tidak terlepas dari permasalahan.

Dalam rangka memberikan informasi akuntansi, maka dibuatlah sebuah sistem informasi yang dikenal dengan sistem informasi akuntansi (SIA). SIA merupakan sistem yang direncanakan dalam sebuah perusahaan untuk menghasilkan informasi yang berguna bagi para penggunanya. SIA adalah komponen dan elemen dari suatu organisasi yang menyediakan informasi bagi pengguna dengan pengolahan peristiwa keuangan (Zare, 2012). Penerapan SIA merupakan kualitas dari kombinasi antara hardware dan software dalam suatu sistem informasi. Hal ini ditunjukkan dengan performa dari suatu sistem yang menunjukkan seberapa baik kemampuan perangkat keras, perangkat lunak, kebijakan, dan prosedur dari suatu sistem informasi dapat menyediakan informasi kebutuhan penggunanya. SIA dapat dikatakan efektif apabila sistem mampu menghasilkan informasi yang dapat diterima dan mampu memenuhi harapan informasi secara tepat waktu (timely), akurat (accurate), dan dapat dipercaya 
(reliable) (Widjajanto, 2001). Sebagai penyedia informasi, SIA selalu berhubungan dengan manusia dalam organisasi. Informasi yang disediakan oleh SIA harus memerhatikan tingkah laku manusia penerimanya, bila tidak menginginkan SIA gagal dalam pengembangan dan penggunaannya. Oleh karena itu faktor manusia sangat menentukan dalam penerapan SIA tersebut.

Kinerja merupakan gambaran tentang pencapaian atau target, pelaksanaan program, usaha, dan kebijakan yang dilakukan untuk mewujudkan visi, misi, dan tujuan dalam kelompok atau organisasi (Mahsun, 2006:145). Kinerja sangat tinggi berarti terjadinya peningkatan efisiensi, efektivitas, dan kualitas lebih baik dalam menyelesaikan tugas-tugas yang akan dibebankan ke setiap individu (Murty dan Hudiwinarsih, 2012). Kinerja karyawan yang baik jika mempunyai keahlian (skill) yang tinggi, bersedia bekerja apabila mendapat imbalan (gaji) atau diberi sesuai dengan kesepakatan, serta memiliki masa depan dan harapan yang baik (Prawirosentini, 1999:3).

Sistem informasi dikatakan sukses apabila sistem tersebut dapat dijalankan dengan baik, mudah digunakan, dan sesuai dengan teknologi yang ada. Keberhasilan suatu sistem informasi dapat diukur dari kepuasan pengguna. Dole dan Schroeder (2001) mengartikan kepuasan kerja sebagai rasa dan reaksi individu pada lingkungan tempat kerjanya. Terciptanya kepuasan kerja anggota organisasi merupakan salah satu sasaran utama dalam manajemen sumber daya manusia pada suatu organisasi, karena hal tersebut akan berdampak pada peningkatan kinerja karyawan yang kemudian diiringi dengan peningkatan kinerja 
A.A Bagus Surya Nayaka dan I Made Sadha Suardikha. Kepuasan...

organisasi. Pencapaian kinerja biasanya dikaitkan dengan prilaku dari pekerja selama proses penilaian. Puas tidaknya pengguna pada suatu sistem informasi tidak dilihat pada kualitas sistem secara teknik, namun dilihat dari cara pemakai memandang sistem informasi tersebut secara nyata, (Guimaraes, et al. 2003).

Selain itu, untuk menghasilkan kinerja yang optimal dalam suatu organisasi dapat diukur dari hasil pekerjaan yang telah dilakukan karyawan. Melalui pencapaian kinerja masing-masing individu maka perusahaan dapat menghasilkan kinerja seutuhnya dan mencapai keberhasilan sesuai dengan apa yang diharapkan perusahaan. Menurut Moeheriono (2009) kompetensi mempunyai peranan yang sangat penting, karena pada umumnya kompetensi menyangkut kemampuan dalam seseorang untuk melakukan suatu pekerjaan. Kompetensi yang wajib dimiliki oleh karyawan adalah salah satunya integritas karena karyawan yang berintegritas akan menciptakan budaya yang berintegritas dalam perusahaan dan selanjutnya menciptakan lingkungan perusahaan yang sangat bernilai, sehingga perusahaan dapat lebih fokus pada situasi jangka panjang yang baik dari karyawan, pelanggan dan investor yang berakibat pada keunggulan dalam kinerja perusahaan.

Terdapat banyak model penelitian yang dikembangkan untuk mengetahui faktor-faktor yang memengaruhi minat dan penggunaan suatu sistem teknologi. Salah satu yang terbaru adalah model Unified Theory of Acceptance and Use of Technology (UTAUT). UTAUT merupakan model penerimaan teknologi yang dikembangkan oleh Venkatesh et al. (2003). Model ini disusun berdasarkan teori- 
teori dasar mengenai perilaku pengguna teknologi dan model penerimaan teknologi. UTAUT menggabungkan fitur-fitur yang berhasil dari delapan teori penerimaan teknologi lainnya yaitu Theory of Reasoned Action (TRA), Innovation Diffusion Theory (IDT), Technology Acceptance Model (TAM), Motivation Model (MM), Theory of Planned Behavior (TPB), Model of PC Utilization (MPCU), Combined TAM-TPB (C-TAM-TPB), dan Social Cognitive Theory (SCT). Model UTAUT dipengaruhi langsung oleh empat faktor utama yaitu ekspektasi kinerja, ekspektasi usaha, faktor sosial, dan kondisi yang memfasilitasi. Selain itu, model UTAUT juga menggunakan empat variabel moderator, yaitu jenis kelamin, umur, pengalaman, dan penggunaan sukarela. Berdasarkan penelitian Venkatesh et al. (2003) model UTAUT berkontribusi sebesar 70\% pada niat penggunaan sehingga untuk sementara dapat dikatakan lebih baik jika dibandingkan dengan delapan model yang ada.

Industri perbankan di Indonesia merupakan salah satu sektor perekonomian yang mengalami perkembangan dinamis dibandingkan sektor ekonomi yang lain. Bank merupakan salah satu penggerak perekonomian bagi suatu negara yaitu dalam hal pembangunan, karena pembangunan ekonomi sangat erat hubungannya dengan kontribusi nyata dan dinamika perkembangan sektor perbankan. Salah satu bank milik Pemerintah Daerah yang ada di Bali yaitu PT. Bank Pembangunan Daerah Bali (BPD Bali). BPD Bali sebagai satu-satunya bank milik Pemerintah Daerah Bali yang diberi kepercayaan oleh Departemen Dalam Negeri untuk mengelola dana-dana daerah serta menyalurkan dana-dana 
A.A Bagus Surya Nayaka dan I Made Sadha Suardikha. Kepuasan...

pembangunan yang berasal dari APBN dan APBD. Oleh karena itu, kinerja BPD Bali sangat diperhatikan oleh Pemerintah Daerah mengingat peranannya sangat besar dalam pengelolaan dana daerah. Penelitian dilakukan di BPD Bali seputar Kota Denpasar, dikarenakan Kota Denpasar adalah kota yang produktif, karena menurut Sumardhana (2013), menyebutkan bahwa, sebaran penyaluran kredit UMKM maupun pribadi oleh sektor perbankan di Bali didominasi oleh Kota Denpasarsebesar 55,5\%. Sehingga penggunaan teknologi informasi dibutuhkan demi memenuhi kebutuhan nasabahnya.

Sepanjang tahun 2017, BPD Bali mampu mencapai kinerja yang baik dari sisi penghimpunan Dana Pihak Ketiga (DPK) dan penyaluran kredit. DPK yang berhasil dihimpun BPD Bali hingga November 2017 mencapai Rp 19,7 triliun, meningkat sebesar 16,93\% dibandingkan November 2016. Sedangkan kredit yang disalurkan hingga November 2017 mencapai Rp 16,2 triliun, meningkat sebesar 4,47\% dibandingkan November 2016. Selain itu, BPD Bali memeroleh peringkat kedua dalam penilaian tingkat kesehatan bank, yang mencerminkan kondisi bank yang secara umum sehat (Maya, 2017).

BPD Bali melakukan investasi yang besar dalam pengadaan sistem informasi, khususnya SIA, untuk meningkatkan kinerja karyawan. Hal ini bisa dilihat dari pengembangan teknologi pada BPD Bali yang diarahkan kepada tersedianya sistem informasi pada seluruh unit kerja. Saat ini di seluruh kantor operasional BPD Bali telah terpasang teknologi online system yang dapat berfungsi untuk memermudah dalam transaksi keuangan. Selain itu, BPD Bali 
juga membantu Lembaga Perkreditan Desa (LPD) yang ada di Bali di dalam pengembangan sistem informasi berbasis komputer agar pelayanan kepada nasabah menjadi lebih cepat. (BPD Bali, 2005)

Sebelumnya beberapa penelitian mengenai pengaruh efektivitas SIA tehadap kinerja karyawan (Sari, 2009; Novita, 2011; Aditya Puja dan Suardhika, 2003; Marlinawati dan Suaryana, 2013) menunjukkan efektivitas penerapan SIA berpegaruh positif signifikan terhadap kinerja karyawan. Di sisi lain terdapat penelitian yang menunjukan bahwa pengadopsian SIA tidak meningkatkan kinerja perusahaan, profitabilitas dan efisiensi operasi di Iran, Malaysia, Spanyol dan Pakistan (Sajady et al. 2008; Kharuddin et al. 2010; Urquia et al. 2011; Kouser et al. 2011).

Adanya kemungkinan hubungan antara penerapan SIA terhadap kinerja karyawan dipengaruhi oleh variabel-variabel lain yang bertindak sebagai variabel moderasi. Variabel moderasi adalah variabel yang memengaruhi (memperkuat atau memperlemah hubungan antara variabel bebas dengan terikat (Sugiyono, 2016:40). Efektifnya kepuasan kerja dan integritas dapat memperkuat atau memperlemah hubungan antara penerapan SIA terhadap kinerja karyawan di suatu organisai.

Peneliti memilih kepuasan kerja sebagai variabel moderasi berdasarkan hasil survei dari situs website JobStreet yang dilakukan pada tahun 2014 dengan 17.623 karyawan sebagai koresponden yang hasilnya menunjukkan bahwa $73 \%$ karyawan tidak puas dengan pekerjaan yang dimiliki. Beberapa faktor yang 
menyebabkan karyawan tidak puas, diantaranya ketidaksesuaian pekerjaan yang ada dengan latar belakang yang dimiliki, tidak adanya keseimbangan antara pekerjaan dengan kehidupan pribadi, serta karyawan yang tidak puas dengan penerapan teknologi pada perusahaannya karena menganggap teknologi tersebut sulit untuk digunakan. Hal ini secara tidak langsung akan berdampak pada kinerja perusahaan.

Sedangkan alasan peneliti memilih integritas sebagai variabel moderasi karena pengangkatan staf yang dilakukan oleh BPD Bali. Karyawan yang pekerjaannya tidak berhubungan dengan komputer, seperti satpam dan sopir, bisa diangkat menjadi staf di BPD Bali. Kegiatan ini dilakukan sebagai bentuk apresiasi kepada karyawan yang memiliki komitmen untuk melakukan pekerjaan sesuai dengan prinsip yang benar dan etis, serta adanya konsistensi untuk tetap melakukan komitmen tersebut pada setiap situasi tanpa melihat adanya peluang ataupun paksaan untuk keluar dari prinsip.

Beberapa penelitian terdahulu menggunakan variabel kepuasan kerja dan integritas sebagai variabel moderasi. Penelitian Antasari (2015) menggunakan variabel kepuasan kerja sebagai variabel moderasi, yang menunjukkan bahwa kepuasan kerja tidak memoderasi pengaruh efektivitas SIA pada kinerja individual. Sedangkan penelitian Dita (2016) menggunakan variabel integritas sebagai variabel moderasi, yang menunjukkan bahwa integritas memoderasi pengaruh penerapan SIA terhadap kinerja karyawan. Penelitian ini menggunakan kedua variabel tersebut sebagai variabel moderasi. 
Adapun tujuan penelitian ini yaitu: 1) Untuk mengetahui pengaruh penerapan SIA pada kinerja karyawan; 2) Untuk mengetahui kepuasan kerjadalam memoderasi pengaruh penerapan SIA pada kinerja karyawan; 3) Untuk mengetahui integritas dalam memoderasi pengaruh penerapan SIA pada kinerja karyawan. Manfaat dari penelitian ini yaitu dapat memberikan kontribusi dalam kajian empiris dan dijadikan perbandingan maupun pengembangan dari penelitian yang sebelumnya.

Unified Theory of Acceptance and Use of Technology (UTAUT) merupakan model penerimaan teknologi yang dikembangkan oleh Venkatesh et al. (2003). Model ini disusun berdasarkan teori-teori dasar mengenai perilaku penggunaan teknologi dan model penerimaan teknologi. Model UTAUT mencoba menjelaskan bagaimana pengaruh perbedaan individual terhadap penggunaan teknologi (Wigyaringtyas, 2014). Model UTAUT dipengaruhi langsung oleh empat faktor utama, salah satunya yaitu ekspektasi usaha. Ekspektasi usaha merupakan tingkat kemudahan penggunaan sistem informasi yang akan dapat mengurangi upaya (tenaga dan waktu) seseorang dalam melakukan pekerjaannya (Venkatesh et al., 2003). Hariani (2013) menyatakan penggunaan sistem informasi yang kurang efektif akan berdampak negatif pada kinerja dan mutu pelayanan organisasi sektor publik pada masyarakat.

Beberapa penelitian menyimpulkan bahwa penerapan SIA berpengaruh terhadap kinerja karyawan. Penelitian Puji (2014) menunjukkan bahwa efektivitas penerapan SIA memiliki pengaruh yang positif dan signifikan terhadap 
A.A Bagus Surya Nayaka dan I Made Sadha Suardikha. Kepuasan...

kinerja karyawan. Penelitian ini sejalan dengan Suhud (2015) yang menyatakan bahwa penerapan SIA berpengaruh positif terhadap kinerja individu. Penerapan SIA akan membantu perusahaan untuk menyajikan laporan keuangan ke dalam bentuk informasi yang akurat dan terpercaya. Hal ini bisa dilihat dari banyak pihak yang memanfaatkan SIA untuk mencapai keunggulan bagi perusahaan. Dengan adanya SIA, karyawan akan menjadi lebih mudah dan cepat dalam menyelesaikan setiap tugas yang diberikan oleh perusahaan, sehingga membantu manajer dalam mengambil suatu keputusan. Berdasarkan uraian diatas dapat disimpulkan hipotesis sebagai berikut.

$\mathrm{H}_{1}$ : Penerapan SIA berpengaruh positif pada kinerja karyawan.

Model UTAUT mencoba menjelaskan bagaimana pengaruh perbedaan individual terhadap penggunaan teknologi (Wigyaringtyas, 2014). Model UTAUT dipengaruhi langsung oleh empat faktor utama, salah satunya yaitu ekspektasi kinerja. Ekspektasi kinerja didefinisikan sebagai seberapa tinggi seseorang percaya bahwa menggunakan suatu sistem akan membantu dirinya untuk mendapatkan keuntungan-keuntungan kinerja dalam pekerjaannya (Venkatesh et al., 2003). Kepuasan para pengguna mencerminkan seberapa jauh pengguna percaya pada suatu sistem informasi yang disediakan dapat memenuhi kebutuhan informasi mereka, atau kepuasan pengguna menggambarkan bagaimana pengguna memandang informasi secara nyata (Guimaraes, et al., 2003)

Beberapa penelitian menyimpulkan bahwa kepuasan kerja berpengaruh terhadap kinerja karyawan. Juniantara (2015) menyatakan kepuasan kerja 
berpengaruh positif dan signifikan terhadap kinerja karyawan. Penelitian ini didukung oleh Al Rizal (2012) yang menyebutkan bahwa kepuasan kerja berpengaruh positif terhadap kinerja karyawan. Kepuasan pengguna sistem informasi sangat penting untuk meningkatkan produktivitas, efisiensi, dan efektivitas dalam menyelesaikan suatu pekerjaan, sehingga akan membawa pada keberhasilan implementasi sistem informasi dengan memberikan dorongan pemakai untuk terus menggunakan sistem tersebut. Berdasarkan uraian diatas dapat disimpulkan hipotesis sebagai berikut.

$\mathrm{H}_{2}$ : Kepuasan kerja memperkuat pengaruh penerapan SIA pada kinerja karyawan.

Model UTAUT mencoba menjelaskan bagaimana pengaruh perbedaan individual terhadap penggunaan teknologi (Wigyaringtyas, 2014). Model UTAUT dipengaruhi langsung oleh empat faktor utama, salah satunya yaitu faktor sosial. Faktor sosial adalah tingkat kepercayaan seseorang terhadap orang lain yang meyakinkan dirinya untuk menggunakan suatu sistem yang baru (Venkatesh et al., 2003). Faktor sosial berpengaruh pada perilaku individu melalui tiga mekanisme, yaitu : kepatuhan, internalisasi, dan identifikasi (Venkatesh dan Davis, 2000). Hal ini sesuai dengan definisi integritas sebagai kualitas yang mendasari kepercayaan publik dan merupakan patokan bagi anggota dalam menguji semua keputusannya (Ayuningtyas, 2012).

Beberapa penelitian menyimpulkan bahwa integritas berpengaruh terhadap kinerja karyawan. Penelitian Erina et al. (2012) menunjukan bahwa integritas memiliki pengaruh positif dan signifikan terhadap kinerja karyawan. Hal tersebut 
juga sejalan dengan yang dikatakan Kirana (2016) yang menyatakan bahwa kinerja auditor internal dipengaruhi oleh integritas. Karyawan yang berintegritas akan menciptakan budaya yang berintegritas dalam perusahaan, dan budaya yang berintegritas ini selanjutnya akan menciptakan lingkungan perusahaan yang bernilai, sehingga perusahaan dapat lebih fokus pada situasi jangka panjang yang lebih baik bagi kayawan, pelanggan, dan investor yang berakibat keunggulan dalam kinerja perusahaan. Begitu juga karyawan yang menggunakan sistem informasi yang memiliki integritas akan meningkatkan kepercayaan bagi pelanggan dan investor, karena hanya orang yang berintegritas yang baik untuk dijadikan partner dalam bekerja. Oleh karena itu integritas merupakan kualitas yang mendasari kepercayaan publik yang diukur dalam bentuk apa yang benar dan adil. Berdasarkan uraian diatas dapat disimpulkan hipotesis sebagai berikut.

$\mathrm{H}_{3}$ : Integritas memperkuat pengaruh penerapan SIA pada kinerja karyawan.

\section{METODE PENELITIAN}

Pendekatan yang digunakan dalam penelitian ini adalah pendekatan kuantitatif yang berbentuk asosiatif, yang bertujuan untuk mengetahui hubungan antara dua variabel atau lebih (Sugiyono, 2016:14). Penelitian ini dilakukan untuk mengetahui hasil antara pengaruhpenerapan SIA pada kinerja karyawan dengan kepuasan kerja dan integritas sebagai variabel moderasinya. Desain penelitian ini dapat digambarkan sebagai berikut:

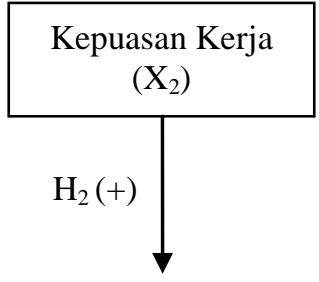




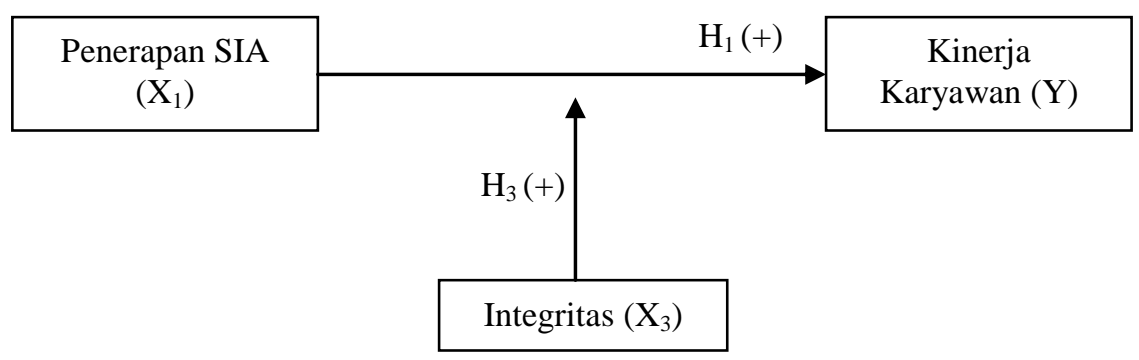

Sumber: Data diolah, 2018

\section{Gambar 1. Desain Penelitian}

Variabel bebas dalam penelitian ini adalah penerapan SIA. Instrumen yang digunakan untuk mengukur penerapan SIA diadopsi dari kuisioner pada penelitian Intan (2017) dengan modifikasi. Model pengukurannya terdiri dari empat indikator, yaitu keamanan data, variasi laporan, ketelitian, dan waktu. Setiap responden diminta untuk menyatakan pendapat responden dengan empat point skala Likert antara (1) sangat tidak setuju sampai (4) sangat setuju.

Variabel terikat dalam penelitian ini adalah kinerja karyawan. Instrumen yang digunakan untuk mengukur kinerja karyawan adalah dengan mengadopsi kuisioner dari penelitian Dita (2016) dengan modifikasi. Model pengukurannya terdiri dari lima indikator, yaitu efektifitas, tanggung jawab, kuantitas, kualitas, dan pelayanan tepat waktu. Setiap responden diminta untuk menyatakan pendapat responden dengan empat point skala Likert antara (1) sangat tidak setuju sampai (4) sangat setuju.

Variabel moderasi dalam penelitian ini adalah kepuasan kerja dan integritas. Instrumen yang digunakan untuk mengukur kepuasan kerja adalah dengan mengadopsi kuisioner dari penelitian Putrawan (2017) dengan modifikasi. Model pengukurannya terdiri dari tiga indikator, yaitu efisiensi, efektif, dan 
A.A Bagus Surya Nayaka dan I Made Sadha Suardikha. Kepuasan...

akuntabel. Setiap responden diminta untuk menyatakan pendapat responden dengan empat point skala Likert antara (1) sangat tidak setuju sampai (4) sangat setuju. Instrumen yang digunakan untuk mengukur integritas karyawan adalah dengan mengadopsi kuisioner dari penelitian Dita (2016) dengan modifikasi. Model pengukurannya terdiri dari tiga indikator, yaitu keberanian, tanggung jawab, dan kejujuran. Setiap responden diminta untuk menyatakan pendapat responden dengan empat point skala Likert antara (1) sangat tidak setuju sampai (4) sangat setuju.

Penelitian ini dilakukan pada BPD Bali di Kota Denpasar, yang terdiri dari 2 Kantor Cabang dan 10 Kantor Cabang Pembantu (Capem). BPD Bali dipilih sebagai lokasi penelitian karena BPD Bali merupakan salah satu bank milik Pemerintah Daerah yang telah menggunakan SIA khususnya pada komputer. Alasan memilih BPD Bali di daerah Kota Denpasar dikarenakan Kota Denpasar adalah kota yang produktif, karena menurut Sumardhana (2013), menyebutkan bahwa sebaran penyaluran kredit UMKM maupun pribadi oleh sektor perbankan di Bali didominasi oleh Kota Denpasar sebesar 55,5\% sehingga penggunaan teknologi informasi dibutuhkan demi memenuhi kebutuhan nasabahnya.

Jenis data yang digunakan dalam penelitian ini adalah data kuantitatif yaitu data yang berbentuk angka atau data kualitatif yang diangkakan (Sugiyono, 2016:23). Data kuantitatif yang digunakan dalam penelitian ini adalah hasil jawaban kuisioner yang telah diberi skor dengan bantuan skala Likert yang 
mengacu pada pengukuran masing-masing serta jumlah responden pada masingmasing sampel pada BPD Bali di Kota Denpasar.

Berdasarkan sumbernya, data yang digunakan dalam penelitian ini adalah data primer yaitu data yang dikumpulkan pertama kali oleh peneliti untuk tujuan penelitiannya (Sugiyono, 2016:31). Data primer pada penelitian ini yaitu berupa hasil survei lewat kuisioner, dimana respondennya adalah karyawan BPD Bali di Kota Denpasar yang menggunakan SIA.

Populasi adalah wilayah generalisasi yang terdiri atas obyek/subyek yang mempunyai kualitas dan karakteristik tertentu yang ditetapkan oleh peneliti untuk dipelajari dan kemudian ditarik kesimpulannya (Sugiyono, 2016:90). Populasi dalam penelitian ini adalah seluruh Kantor Cabang dan Kantor Capem BPD Bali yang tersebar di Kota Denpasar. Dari 12 BPD Bali di Kota Denpasar, baik Kantor Cabang maupun Kantor Capem, yang terdiri atas staf kredit sebanyak 34 orang, dana \& jasa sebanyak 2 orang, teller sebanyak 31 orang, back office sebanyak 9 orang, dan penyelamatan kredit sebanyak 4 orang, maka subjek penelitian ini menjadi 80 orang. Sampel adalah bagian dari jumlah dan karakteristik yang dimiliki oleh populasi tersebut (Sugiyono, 2016:91). Sampel dalam penelitian ini berjumlah 80 karyawan. Teknik sampling yang digunakan adalah non-probability sampling dengan metode sampling jenuh yaitu teknik penentuan sampel, bila semua anggota populasi digunakan sebagai sampel (Sugiyono, 2016:96).

Metode pengumpulan data pada penelitian ini menggunakan metode survei dengan teknik pengumpulan data yang digunakan berupa kuisioner. Teknik 
analisis data yang digunakan dalam penelitian ini untuk menguji hipotesis pertama akan dianalisis dengan menggunakan alat analisis regresi linier sederhana. Regresi linier sederhana didasarkan pada hubungan fungsional ataupun kasual atau variabel bebas dengan satu variabel terikat. Digunakannya regresi linier sederhana disebabkan karena peneliti merasa belum yakin terhadap pengaruh penerapan SIA pada kinerja karyawan, yang dibuktikan dengan masih terdapat inkonsistensi dari hasil penelitian terdahulu. Teknik analisis data menggunakan teknik analisis regresi sederhana dengan model persamaan sebagai berikut.

$\mathrm{Y}=\alpha+\beta_{1} \mathrm{X}_{1}+\varepsilon$

Keterangan :

$\mathrm{Y} \quad=$ kinerja karyawan

$\alpha \quad=$ konstanta (tetap)

$\beta_{1}=$ koefisien regresi

$\mathrm{X}_{1}=$ penerapan SIA

$\varepsilon \quad=$ kesalahan prediksi (error)

Metode analisis yang digunakan untuk menguji hipotesis 2 dan 3 yaitu analisis MRA. MRA merupakan aplikasi khusus regresi berganda linier dimana dalam persamaan regresinya mengandung suatu interaksi. Teknik analisis data menggunakan teknik analisis MRA dengan model persamaan sebagai berikut.

$Y=\alpha+\beta_{1} X_{1}+\beta_{2} X_{2}+\beta_{3} X_{3}+\beta_{4} X_{1} X_{2}+\beta_{5} X_{1} X_{3}+\varepsilon$

Keterangan :

$\mathrm{Y} \quad=$ Variabel terikat kinerja karyawan

$\alpha=$ Konstanta (tetap)

$\beta_{1} \quad=$ Koefisien penerapan SIA

$\beta_{2} \quad=$ Koefisien kepuasan kerja

$\beta_{3} \quad=$ Koefisien integritas

$\beta_{4} \quad=$ Koefisien penerapan SIA dan kepuasan kerja

$\beta_{5} \quad=$ Koefisien penerapan SIA dan integritas

$\mathrm{X}_{1} \quad=$ Variabel bebas penerapan SIA

$\mathrm{X}_{2}=$ Variabel moderasi kepuasan kerja 


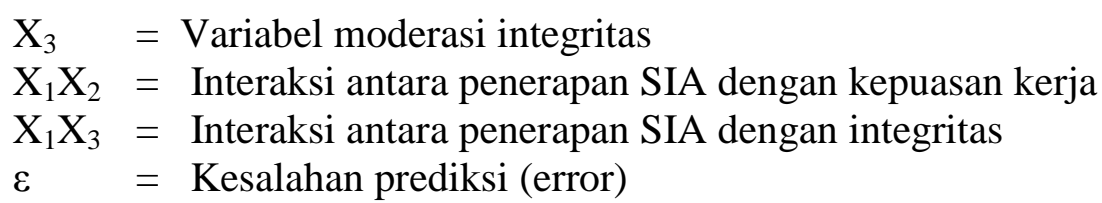

\section{HASIL DAN PEMBAHASAN}

Uji validitas digunakan untuk mengukur valid atau tidaknya suatu kuisioner (Ghozali, 2016:52). Uji validitas dilakukan dengan bantuan program SPSS dengan menghitung korelasi antara skor masing-masing butir pertanyaan atau pernyataan dengan total skor sehingga dihasilkan nilai Pearson Correlation. Sugiyono (2016:178) mengatakan suatu instrumen akan dikatakan valid apabila nilai Pearson Correlation terhadap skor total diatas $0,3(\mathrm{r} \geq 0,3)$. Hasil uji validitas pada penelitian ini menunjukkan bahwa instrumen yang digunakan dalam penelitian ini terdiri dari item-item pernyataan mengenai penerapan SIA, kepuasan kerja, integritas, dan kinerja karyawan adalah valid karena nilai Pearson Correlation positif dan besarnya di atas 0,3 .

Pengujian reliabilitas dilakukan untuk mengukur sebuah kuisioner yang menunjukkan indikator dari variabel. Suatu kuisioner dikatakan reliabel apabila jawaban responden terhadap pernyataan adalah konsisten dari waktu ke waktu (Ghozali, 2016:48). Uji ini dilakukan terhadap instrumen dengan koefisien Cronbach's Alpha. Apabila nilai koefisiennya lebih besar dari 0,6 maka instrumen yang digunakan reliabel. Hasil uji reliabilitas penelitian ini menunjukkan bahwa nilai Cronbach's Alpha dari masing-masing variabel lebih besar dari 0,6 yang artinya bahwa seluruh pernyataan dalam kuisioner penelitian ini reliabel dan dapat digunakan. 
Statistik deskriptif memberikan gambaran mengenai pemahaman kinerja karyawan, penerapan SIA, kepuasan kerja, dan integritas terkait dengan nilai ratarata, standar deviasi, nilai minimum, dan nilai maksimum. Tabel 1. menunjukkan hasil statistik deskriptif.

\section{Tabel 1.}

Hasil Statistik Deskriptif

\begin{tabular}{cccccc}
\hline Variabel & N & Min. & Max. & Mean & Std. Deviasi \\
\hline $\mathrm{X}_{1}$ & 80 & 2,00 & 4,00 & 3,2781 & 0,7454 \\
$\mathrm{X}_{2}$ & 80 & 2,00 & 4,00 & 3,2500 & 0,7691 \\
$\mathrm{X}_{3}$ & 80 & 2,00 & 4,00 & 3,3792 & 0,7305 \\
$\mathrm{Y}$ & 80 & 2,00 & 4,00 & 3.3000 & 0,7383 \\
\hline
\end{tabular}

Sumber:Data diolah, 2018

Berdasarkan hasil pengujian analisis statistik deskriptif pada Tabel 1. menunjukkan bahwa variabel penerapan SIA $\left(X_{1}\right)$ memiliki nilai terendah 2,00, nilai tertinggi 4,00, dan nilai rata-rata 3,2781. Standar deviasi sebesar 0,7454, hal ini menunjukkan bahwa terjadi perbedaan nilai penerapan SIA yang diteliti dengan nilai rata-ratanya sebesar 0,7454. Nilai rata-rata sebesar 3,2781 menunjukkan secara rata-rata jawaban responden cenderung mengarah ke nilai tertinggi yaitu 3,3250 yang terdapat pada pernyataan bahwa sistem yang disediakan dapat meningkatkan kecepatan waktu dalam pelayanan terhadap customer, yang artinya penerapan SIA cenderung berdampak positif terhadap peningkatan kinerja karyawan.

Variabel kepuasan kerja $\left(\mathrm{X}_{2}\right)$ memiliki nilai terendah 2,00, nilai tertinggi 4,00, dan nilai rata-rata 3,2500. Standar deviasi sebesar 0,7691, hal ini menunjukkan bahwa terjadi perbedaan nilai kepuasan kerja yang diteliti dengan nilai rata-ratanya sebesar 0,7691 . Nilai rata-rata sebesar 3,2500 menunjukkan secara rata-rata jawaban responden cenderung mengarah ke nilai tertinggi yaitu 
3,3000 yang terdapat pada pernyataan bahwa SIA yang berbasis TI dapat membawa hasil atau tujuan sesuai harapan dan target yang diinginkan, yang artinya tingkat kepuasan kerja yang tinggi cenderung memberikan dampak positif terhadap peningkatan kinerja karyawan.

Variabel integritas $\left(\mathrm{X}_{3}\right)$ memiliki nilai terendah 2,00, nilai tertinggi 4,00, dan nilai rata-rata 3,3792. Standar deviasi sebesar 0,7305, hal ini menunjukkan bahwa terjadi perbedaan nilai integritas yang diteliti dengan nilai rata-ratanya sebesar 0,7305. Nilai rata-rata sebesar 3,3792 menunjukkan secara rata-rata jawaban responden cenderung mengarah ke nilai tertinggi yaitu 3,3875 yang terdapat pada pernyataan bahwa sistem yang disediakan dapat meningkatkan rasa tanggung jawab karyawan, yang artinya tingkat integritas yang tinggi cenderung memberikan dampak positif terhadap peningkatan kinerja karyawan.

Variabel kinerja karyawan (Y) memiliki nilai terendah 2,00, nilai tertinggi 4,00, dan nilai rata-rata 3,3000. Standar deviasi sebesar 0,7383, hal ini menunjukkan bahwa terjadi perbedaan nilai kinerja karyawan yang diteliti dengan nilai rata-ratanya sebesar 0,7383 . Nilai rata-rata sebesar 3,3000 menunjukkan secara rata-rata jawaban responden cenderung mengarah ke nilai tertinggi yaitu 3,3500 yang terdapat pada pernyataan bahwa pemanfaatan teknologi informasi mambantu dalam melaksanakan tanggung jawab pekerjaan dengan baik, yang artinya responden cenderung mengalami peningkatan kinerja dengan adanya penerapan SIA. 
Sebelum dilakukan analisis melalui teknik regresi, model persamaan regresi harus melewati uji asumsi klasik. Model persamaan regresi dikatakan baik dan dapat diuji apabila tidak terdapat masalah data yang tidak berdistribusi normal serta bebas dari uji multikolinieritas dan uji heteroskedastisitas. Uji statistik yang digunakan untuk menguji normalitas dalam penelitian ini adalah uji statistik nonparametrik Kolmogorov-Smirnov (K-S). Hasil uji normalitas pada penelitian ini menunjukkan nilai signifikansi untuk persamaan model pertama dan kedua adalah sebesar 0,200 $(0,200>0,05)$. Hal ini menunjukkan bahwa model regresi pada penelitian ini berdistribusi normal.

Uji multikolinearitas bertujuan untuk menguji apakah model regresi ditemukan adanya korelasi antar variabel bebas (Ghozali, 2016:103). Uji ini dilakukan dengan melihat nilai tolerance atau Variance Inflation Factor (VIF). Hasil uji multikolineartitas pada penelitian ini menunjukkan bahwa nilai tolerance tiap variabel lebih besar dari 0,1 dan nilai VIF lebih kecil dari 10. Sehingga dapat disimpulkan bahwa dalam model regresi MRA tidak terjadi multikolinieritas. Uji heteroskedastisitas dilakukan untuk mengetahui apakah di dalam model regresi terjadi ketidaksamaan varian pada residual dari satu pengamatan ke pengamatan lainnya. Uji heteroskedastisitas dapat dilakukan dengan uji Glejser. Hasil uji heteroskedastisitas pada penelitian ini menunjukkan nilai signifikansi masingmasing variabel lebih besar dari 0,05 . Hal ini dapat disimpulkan bahwa tidak terjadi heteroskedastisitas pada model regresi dalam penelitian ini. Berdasarkan 
ISSN: 2302-8556

E-Jurnal Akuntansi Universitas Udayana Vol.26.1.Januari (2019): 454-483

hasil uji normalitas, dan uji heteroskedastisitas yang diperoleh maka dapat dinyatakan model regresi penelitian ini lolos uji asumsi klasik.

Untuk melihat hasil analisis regresi linier sederhana dan Moderated Regression Analysis (MRA), dapat dilihat pada Tabel 2. dan Tabel 3.

Tabel 2.

Hasil Analisis Regresi Linier Sederhana

\begin{tabular}{lccccr}
\hline \multirow{2}{*}{ Variabel } & \multicolumn{2}{c}{$\begin{array}{c}\text { Unstandardized } \\
\text { Coefficients }\end{array}$} & $\begin{array}{c}\text { Standardized } \\
\text { Coefficients }\end{array}$ & t & Sig. \\
\cline { 2 - 4 } & B & Std. Error & Beta & & \\
\hline Constant & 3,659 & 1,097 & & 3,337 & 0,001 \\
$\mathrm{X}_{1}$ & 0,934 & 0,096 & 0,740 & 9,709 & 0,000 \\
$R$ Square & & & 0,547 & & \\
F hitung & & & 94,271 & & \\
Signifikansi F & & & 0,000 & & \\
Sumber:Data diolah 2018 & & & & &
\end{tabular}

Tabel 3.

Hasil Moderated Regression Analysis (MRA)

\begin{tabular}{lccccc}
\hline \multirow{2}{*}{ Variabel } & \multicolumn{2}{c}{$\begin{array}{c}\text { Unstandardized } \\
\text { Coefficients }\end{array}$} & $\begin{array}{c}\text { Standardized } \\
\text { Coefficients }\end{array}$ & T & \multirow{2}{*}{ Sig. } \\
\cline { 2 - 4 } & $\mathbf{B}$ & Std. Error & Beta & & \\
\hline Constant & 1,505 & 2,032 & & 0,741 & 0,461 \\
$\mathrm{X}_{1}$ & 0,176 & 0,246 & 0,139 & 0,714 & 0,477 \\
$\mathrm{X}_{2}$ & $-0,249$ & 0,391 & $-0,156$ & $-0,637$ & 0,526 \\
$\mathrm{X}_{3}$ & 1,302 & 0,258 & 0,816 & 5,051 & 0,000 \\
$\mathrm{X}_{1} \mathrm{X}_{2}$ & 0,072 & 0,034 & 0,783 & 2,128 & 0,037 \\
$\mathrm{X}_{1} \mathrm{X}_{3}$ & $-0,056$ & 0,031 & $-0,619$ & $-1,826$ & 0,072 \\
$R$ Square & & & 0,785 & & \\
F hitung & & & 58,778 & & \\
Signifikansi F & & & 0,000 & & \\
\hline Sumber: Data diolah 2018 & & & &
\end{tabular}

Berdasarkan Tabel 2. dan Tabel 3., dapat dilihat perbandingan hasil uji koefisien determinasi, dimana jika dilihat dari nilai $\mathrm{R}^{2}$, hasil uji regresi linier sederhana lebih kecil daripada hasil uji regresi moderasi. Masuknya variabel moderasi dan interaksi antara variabel moderasi dan variabel bebas telah menyebabkan kenaikan pada koefisien determinasi $\left(\mathrm{R}^{2}\right)$. Nilai $\mathrm{R}^{2}$ dari hasil regresi linier sederhana digunakan untuk mengetahui seberapa besar pengaruh variabel 
bebas terhadap variabel terikat. Berdasarkan Tabel 2., nilai $\mathrm{R}^{2}$ sebesar 0,547 , hal ini berarti 54,7\% variasi kinerja karyawan dipengaruhi oleh variasi penerapan SIA $\left(\mathrm{X}_{1}\right)$ dan sisanya sebesar $45,3 \%$ dipengaruhi oleh faktor lain di luar model penelitian.

Nilai $\mathrm{R}^{2}$ dari hasil regresi moderasi digunakan untuk mengetahui seberapa besar pengaruh variabel bebas, variabel moderasi dan interaksi antara variabel moderasi dan variabel bebas terhadap variabel terikat. Berdasarkan Tabel 3., nilai $\mathrm{R}^{2}$ sebesar 0,785 , hal ini berarti $78,5 \%$ variasi kinerja karyawan dipengaruhi oleh variasi penerapan SIA $\left(\mathrm{X}_{1}\right)$, kepuasan kerja $\left(\mathrm{X}_{2}\right)$, integritas $\left(\mathrm{X}_{3}\right)$, interaksi antara penerapan SIA dengan kepuasan kerja $\left(\mathrm{X}_{1} \mathrm{X}_{2}\right)$, dan interaksi antara penerapan SIA dengan integritas $\left(\mathrm{X}_{1} \mathrm{X}_{3}\right)$. Sisanya sebesar $21,5 \%$ dipengaruhi oleh faktor lain di luar model penelitian.

Uji kelayakan model bertujuan untuk menguji apakah model yang digunakan dalam penelitian ini layak untuk digunakan atau tidak (Ghozali, 2016:98). Berdasarkan Tabel 2. dan Tabel 3., baik tanpa maupun dengan moderasi, nilai signifikansi $\mathrm{F}$ atau $p$-value dari kedua tabel sebesar 0,000 dan 0,000 yang lebih kecil dari nilai $\alpha=0,05$. Hal ini menunjukkan bahwa model regresi linier sederhana dan regresi moderasi layak digunakan sebagai alat analisis untuk menguji pengaruh variabel bebas pada variabel terikat.

Berdasarkan hasil analisis regresi linier sederhana pada Tabel 2 . menunjukkan nilai signifikansi t sebesar 0,000 yang lebih kecil dari 0,05, sehingga $\mathrm{H}_{0}$ ditolak dan $\mathrm{H}_{1}$ diterima. Hal ini menunjukkan bahwa secara parsial 
penerapan SIA berpengaruh pada kinerja karyawan. Hal ini berarti SIA yang telah diterapkan pada BPD Bali di Kota Denpasar mampu meningkatkan kinerja para karyawan. Hal ini dapat dikaitkan dengan teori UTAUT mengenai salah satu faktor yang memengaruhi minat pemanfaatan dan penggunaan sistem informasi, yaitu ekspektasi usaha. Penerapan SIA pada BPD Bali di Kota Denpasar dapat mempermudah dan mempercepat penyelesaian tugas yang dilakukan setiap individu di lembaga tersebut.

Hasil pengujian hipotesis ini sejalan dengan penelitian yang dilakukan Sari (2009), Novita (2011), dan Suhud (2015) yang menunjukkan bahwa adanya pengaruh positif antara penerapan SIA pada kinerja karyawan. Penerapan SIA akan membantu perusahaan untuk menyajikan laporan keuangan ke dalam bentuk informasi yang akurat dan terpercaya. Hal ini bisa dilihat dari banyak pihak yang memanfaatkan SIA untuk mencapai keunggulan bagi perusahaan. Dengan adanya SIA, karyawan akan menjadi lebih mudah dan cepat dalam menyelesaikan setiap tugas yang diberikan oleh perusahaan, sehingga membantu manajer dalam mengambil suatu keputusan.

Berdasarkan hasil pengujian MRA pada Tabel 3. menunjukkan nilai signifikansi t sebesar 0,037 yang lebih kecil dari 0,05, sehingga $\mathrm{H}_{0}$ ditolak dan $\mathrm{H}_{2}$ diterima. Hal ini menunjukkan bahwa kepuasan kerja memoderasi pengaruh penerapan SIA pada kinerja karyawan. Hal ini berarti semakin tinggi kepuasan kerja seseorang, maka akan meningkatkan kinerja karyawan pada BPD Bali di Kota Denpasar. Interaksi antara variabel penerapan SIA dengan kepuasan kerja 
A.A Bagus Surya Nayaka dan I Made Sadha Suardikha. Kepuasan...

$\left(\mathrm{X}_{1} \mathrm{X}_{2}\right)$ disebut pure moderator (moderasi murni) yakni dapat dilihat dari nilai $\beta_{2}$ non significant dan $\beta_{4}$ significant.

Kepuasan kerja yang diterima dan dirasakan oleh seorang karyawan akan berpengaruh terhadap hasil yang diperoleh dari pekerjaannya (Abdulloh, 2006). Hal ini dapat dikaitkan dengan teori UTAUT mengenai salah satu faktor yang memengaruhi minat pemanfaatan dan penggunaan sistem informasi, yaitu ekspektasi kinerja. Seorang karyawan yang telah memiliki kepuasan kerja, dalam hal ini berkaitan dengan penggunaan sistem informasi, berarti telah percaya bahwa menggunakan suatu sistem akan membantu dirinya untuk mendapatkan keuntungan-keuntungan kinerja dalam pekerjaannya.

Hasil pengujian hipotesis ini sejalan dengan penelitian yang dilakukan $\mathrm{Al}$ Rizal (2012) dan Juniantara (2015) yang menunjukkan bahwa adanya pengaruh positif dan signifikan antara kepuasan kerja dengan kinerja karyawan. Kepuasan pengguna sistem informasi sangat penting untuk meningkatkan produktivitas, efisiensi, dan efektivitas dalam menyelesaikan suatu pekerjaan, sehingga akan membawa pada keberhasilan implementasi sistem informasi dengan memberikan dorongan pemakai untuk terus menggunakan sistem tersebut.

Hasil pengujian MRA pada Tabel 3. Menunjukkan nilai signifikansi t sebesar 0,072 yang lebih besar dari 0,05, sehingga $\mathrm{H}_{0}$ diterima dan $\mathrm{H}_{3}$ ditolak. Hal ini menunjukkan bahwa integritas tidak memoderasi pengaruh penerapan SIA pada kinerja karyawan. Hal ini berarti integritas yang dimiliki karyawan tidak memengaruhi penerapan SIA pada kinerja karyawan. Interaksi antara variabel 
penerapan SIA dengan integritas $\left(\mathrm{X}_{1} \mathrm{X}_{3}\right)$ disebut predictor moderator (prediktor moderasi) yakni dapat dilihat dari nilai $\beta_{3}$ significant dan $\beta_{5}$ non significant.

Seluruh karyawan di BPD Bali yang bekerja di bagian staf kredit, dana \& jasa, teller, back office, serta penyelamatan kredit diwajibkan untuk menggunakan SIA yang telah disediakan, agar menghasilkan kinerja yang lebih baik. Hal ini dapat dikaitkan dengan teori UTAUT mengenai salah satu faktor yang memengaruhi minat pemanfaatan dan penggunaan sistem informasi, yaitu faktor sosial, dimana pimpinan perusahaan mewajibkan para karyawan untuk menggunakan SIA yang telah disediakan dalam menyelesaikan tugas-tugas yang diberikan.

Di dalam penerimaan karyawan baru di BPD Bali, terdapat tes mengenai integritas yang termasuk ke dalam tes psikologis. Namun masih terdapat beberapa karyawan yang di dalam kegiatan sehari-harinya di perusahaan tidak sesuai dengan hasil tes psikologis, khususnya mengenai integritas, seperti tidak pernah mengeluarkan pendapat di saat rapat, bersikap taat hanya saat ada pimpinan atau manajer saja, dan tidak menghargai tata tertib kantor. Meskipun demikian, BPD Bali mampu mencapai kinerja yang baik dengan memperoleh peringkat kedua dalam penilaian tingkat kesehatan bank oleh OJK, yang mencerminkan kondisi bank yang secara umum sehat.

\section{SIMPULAN}

Berdasarkan hasil penelitian yang telah dilakukan, maka dapat ditarik simpulan sebagai berikut: 1) Penerapan SIA berpengaruh positif pada kinerja karyawan. Hal 
ini menunjukkan bahwa penerapan SIA pada BPD Bali di Kota Denpasar dapat memermudah dan mempercepat penyelesaian tugas yang dilakukan setiap karyawan di lembaga tersebut; 2) Kepuasan kerja memperkuat pengaruh penerapan SIA pada kinerja karyawan. Hal ini menunjukkan bahwa dengan diperolehnya kepuasan kerja oleh karyawan di dalam penggunaan SIA yang telah diterapkan, maka dapat membantu memperlancar dalam menyelesaikan tugas yang diberikan; 3) Integritas tidak memoderasi pengaruh penerapan SIA pada kinerja karyawan. Hal ini disebabkan seluruh karyawan di BPD Bali yang bekerja di bagian staf kredit, dana \& jasa, teller, back office, serta penyelamatan kredit diwajibkan untuk menggunakan SIA yang telah disediakan, agar menghasilkan kinerja yang lebih baik.

Berdasarkan hasil penelitian diperoleh hasil $R$ square sebesar 79 persen yang menunjukkan bahwa masih ada 21 persen faktor lain di luar model yang memengaruhi kinerja karyawan, sehingga saran yang diberikan bagi peneliti selanjutnya dapat menambahkan variabel lainnya yang dapat memengaruhi dan memperkuat kinerja karyawan.

\section{REFERENSI}

Abdulloh. 2006. Pengaruh Budaya Organisasi Locus of Control dan Kepuasan Kerja terhadap Kinerja Karyawan pada Kantor Pelayanan Pajak Semarang Barat. Tesis. Universitas Diponegoro, Semarang.

Aditya Puja, Pratama. G. dan Suardikha, I Md. Sadha. 2013. Keahlian Pemakai Komputer dan Kenyamanan Fisik Memoderasi Pengaruh Efektivitas Sistem Informasi Akuntansi terhadap Kinerja Karyawan di PT. Bank Sinar Harapan Bali Denpasar. E-Jurnal Akuntansi Universitas Udayana, 5(2), pp: 361-381. 
Al Rizal, M. Hanif. 2012. Pengaruh Budaya Organisasi Dan Kepuasan Kerja Terhadap Kinerja Karyawan. Skripsi. Fakultas Ekonomika dan Bisnis Universitas Diponegoro, Semarang.

Alrabei, Ali Mahmoud Abdullah. 2014. The Impact of Accounting Information System on the Islamic Banks of Jordan: An Empirical Study. European Scientific Journal,10(4), pp. 184-198

Antasari, Kadek Chendi. Dan Yaniartha S, Putu D’yan. 2016. Pengaruh Efektivitas Sistem Informasi Akuntansi dan Penggunaan Teknologi Informasi pada Kinerja Individual dengan Kepuasan Kerja sebagai Variabel Pemoderisasi. E-Jurnal Akuntansi Universitas Udayana, 10(2), pp:354-369.

Ayuningtyas, Harvita Yulian. 2012. Pengaruh Pengalaman Kerja, Independensi, Obyektivitas, Integritas, dan Kompetensi terhadap Kualitas Hasil Audit. Skripsi. Fakultas Ekonomika dan Bisnis Universitas Diponegoro, Semarang.

Dita, Made Ambara. dan Putra, I Wayan. 2016. Pengaruh Penerapan Sistem Informasi Akuntansi terhadap Kinerja Karyawan dengan Integritas Karyawan sebagai Variabel Pemoderisasi. E-Jurnal Akuntansi Universitas Udayana, 15(1), pp:614-640.

Dole, Carol. dan Schroeder, Richard G. 2001. The effects of Managerial Roles on the Relation Between Budgetary Participation and Job Satisfaction. Accounting and Finance, May, pp. 1-14.

Erina, Cut., Darmawis., dan Zein, Basri. 2012. Pengaruh Integritas, Obyektivitas, Kerahasiaan dan Kompetensi Terhadap Kinerja Aparat Pengawas Internal Pemerintah (Studi pada Inspektorat Aceh). Jurnal Akuntansi Pascasarjana Universitas Syiah Kuala pp. 15-27.

Ghozali, Imam. 2016. Aplikasi Analisis Multivariative Dengan Program IBM SPSS 23. Semarang: Badan Penerbit Universitas Diponogoro.

Guimaraes, T., D. S. Staples., dan J. D. McKeen. 2003. Empirically Testing Some Main User-Related Factor for Systems Development Quality. Management Journal, 10(4): 39- 54.

Hariani, D., Purbandari, T., dan Mujilan, A. 2013. Dukungan Manajerial dan Budaya Organisasi untuk Menuju Efektivitas Sistem Informasi Akuntansi. JRMA| Jurnal Riset Manajemen dan Akuntansi, 1(2), 29-36. 
Intan Fatmayoni, I Gusti Agung Ayu. 2017. Pengaruh Efektivitas SIA dan Penggunaan Teknologi Informasi pada Kinerja Individual dengan Insentif Karyawan sebagai Pemoderasi.E-Jurnal Akuntansi Universitas Udayana, 19(3), pp:2175-2204.

Juniantara, I Wayan. 2015. Pengaruh Motivasi dan Kepuasan Kerja Terhadap Kinerja Karyawan Koperasi di Denpasar. E-Jurnal Ekonomi dan BisnisUniversitas Udayana, 4(9), pp:611-628.

Kirana, Nita Eka. 2016. Pengaruh Independensi, Integritas, Objektivitas, dan Kerahasiaan terhadap Kinerja Auditor pada Kantor Inspeksi Bank BRI Yogyakarta. Yogyakarta: E-Jurnal Universitas Negeri Yogyakarta, Mei 2016.

Kouser, R., Awan, A., Rana. G., dan Shahzad. F. 2011. Firm Size, Leverage and Prifitability: Overriding Impact of Accounting Information Systems.Journal of Management and Business Review, 1 (10), pp:58-64.

Mahsun, Mohammad. 2006. Pengukuran Kinerja Sektor Publik. Edisi Pertama. Yogyakarta: BPFE.

Marlinawati, Ni Made Ayu dan Suaryana, I.G.N Agung. 2013. Pengaruh Penggunaan Teknologi Informasi, Efektivitas Sistem Informasi Akuntansi, Kepercayaan atas Sistem Informasi Akuntansi, dan Kesesuaian Tugas pada Kinerja Karyawan LPD Kabupaten Badung, Jurnal EkonomiUniversitas Udayana.

Maya, Citta. 2017. Kinerja BPD Bali 2017, Penyaluran Kredit Rp 16,2 triliun. http://www.balipost.com/news/2017/12/22/32257/Kinerja-BPD-Bali2017,Penyaluran...html. Diakses 2 Januari 2018.

Moeheriono 2009. Pengukur Kinerja Berbasis Kompetensi.Jakarta : Ghalia Indonesia.

Murty, W. Aprilia. dan Hudiwinarsih Gunasti. 2012. Pengaruh Kompensasi, Motivasi dan Komitemen Organisasional terhadap Kinerja Karyawan Bagian Akuntansi. Jurnal STIE Perbanas, 2 (2), h:215-228.

Novita, Helena. 2011. Efektivitas Sistem Informasi Akuntansi Dampaknya Terhadap Kinerja Karyawan pada PT Dwi Daya Sentra Perkasa (Persero).Skripsi.Fakultas Teknik dan Ilmu Komputer Universitas Komputer Indonesia. 
Puji Astuti, N. M. M., dan Dharmadiaksa, I. B. 2014. Pengaruh Penerapan Sistem Informasi Akuntansi, Pemanfaatan dan Kesesuaian Tugas terhadap Kinerja Karyawan. E-Jurnal Akuntansi Universitas Udayana, 9(2), h:373-384.

Putrawan, Nyoman Agus. 2017. Analisis Efektivitas Sistem Informasi Manajemen Daerah (SIMDA) Pemerintah Kabupaten Gianyar.E-Jurnal Akuntansi Universitas Udayana, 6(4), pp:1639-1672.

Sajady, H., Dastgir, M., dan Hashem Nejad, H. 2008. Evaluation of The Effectiveness of Accounting Information Systems. International Journal of Information Science \& Technology, 6(2).

Sari, Maria M. Ratna. 2009. Pengaruh Efektivitas Penggunaan dan Kepercayaan terhadap Teknologi Sistem Informasi Akuntansi terhadap Kinerja Individual pada Pasar Swalayan di Kota Denpasar. Jurnal Ilmiah Akuntansi dan Bisnis, 4(1)

Sugiyono, P. D. 2016. Metode Penelitian Kuantitatif, Kualitatif, dan R\&D. Bandung: CV. Alfabeta.

Suhud, Sheilla Puteri. 2015. Pengaruh Penerapan Sistem Informasi Akuntansi terhadap Kinerja Individu Pegawai Distro di Kota Bandung. Skripsi. S-1 Jurusan Akuntansi Universitas Diponegoro.

Sumardhana, I Made. 2013.BPR di Bali Fokus Layani UMKM. Bisnis Bali, 19 Juni2013. Hal. 4. Kol.4.

Urquia Grande, Elena., Estebanez, Raquel P., dan Munoz Colomina, Clara. 2011. The Impact of Accounting Information Systems (AIS) on Perfomance Measures: Empirical Evidence in Spanish SMEsl. The International Journal of Digital Accounting Research, 11, pp.:25-43.

Venkatesh, V. dan Davis, F.D. 2000. A Theoritical Extension of the Technology Aceptance Model: Four Longitudinal Field Studies. Management Science, 46 (2), pp:186-204.

Venkatesh, V., M.G. Morris., G.B. Davis., dan F.D. Davis. 2003. User Acceptance of Information Technology: Toward a Unified View. MIS Querterly, 27 (3), 425-478.

Wigyaringtyas, Tuning Mey. 2014. Analisis Faktor-Faktor yang Memengaruhi Minat Penggunaan Sistem Informasi Terkomputerisasi (Studi pada KSP 
A.A Bagus Surya Nayaka dan I Made Sadha Suardikha. Kepuasan...

di Kab. Semarang). Dissertasi. Program Studi Akuntansi Fakultas Ekonomi dan Bisnis Universitas Kristen Satya Wacana.

Widjajanto, Nugroho. 2001. Sistem Informasi Akuntansi. Jakarta : Erlangga.

Zare, I. 2012. Study of Effect of Accounting Information System and Softwares on Qualitative Features of Accounting Information. Journal of Management Science and Business Research, 1 (4), pp: 1-12. 